\title{
The Role of Semiotics in Translating SYMBOLS FOR BIBLICAL TEXTS
}

\author{
Ni Made Diana Erfiani ${ }^{a}$ *, Ni Nyoman Tri Sukarsih ${ }^{b}$ Putu \\ Chris Susanto $^{\text {c }}$ \\ abc Universitas Dhyana Pura \\ abc Jalan Raya Padang Luwih, Badung, Bali, Indonesia \\ adianaerfiani@undhirabali.ac.id \\ btrisukrsih@undhirabali.ac.id \\ cchris.susanto@undhirabali.ac.id
}

\begin{abstract}
Semiotics, which is the science of signs, has become an increasingly interesting interdisciplinary area of study. As such, semiotics can also be used as both structural and pragmatic approach for translation studies, especially for studies in which meanings are difficult to comprehend including symbolic texts. This paper aims to uncover the role of semiotics in the translation of symbolic languages, especially religious texts. The study employs descriptive qualitative method to describe and interpret the data in the form of an analysis of symbolic text translation. This is to uncover the various attitudes and perspectives about the roles of semiotic science in the translation of religious texts. The findings of this study indicate that the semiotic perspective is able to reveal the dimensions of referential or conceptual meaning of the symbols through the appearance of a supplementary component, which connects literal and figurative meanings conventionally. This effort is carried out through the use of structural semiotic analysis tools, namely by exploring the relationships between symbolic meanings, both syntagmatically and paradigmatically.
\end{abstract}

Keywords: semiotic, translation, symbol, syntagmatic, paradigmatic 


\begin{abstract}
Abstrak
Semiotik yang adalah ilmu tentang tanda telah menjadi wilayah lintas disiplin yang menarik untuk dicermati. Karenanya, semiotik juga dapat digunakan sebagai pendekatan, baik secara struktural maupun pragmatis bagi kajiankajian terjemahan khususnya yang maknanya sulit untuk dipahami termasuk di dalamnya teks simbolis. Tulisan ini bertujuan untuk mengungkap peranan ilmu semiotik dalam penerjemahan Bahasa simbolis khususnya teks religi. Metode yang dipergunakan dalam penelitian ini adalah deskriptif kualitatif. Metode ini dipilih untuk dapat menguraikan dan menafsirkan data berupa contoh analisis penerjemahan teks simbolis guna dapat memunculkan sikap serta pandangan tentang peran ilmu semiotik dalam penerjemahan teks religi. Hasil penelitian ini menunjukkan bahwa cara pandang semiotis mampu mengungkap dimensi makna referensial atau konseptual simbol melalui pemunculan makna tambahan (supplementary component), yang menghubungkan makna harfiah dan figuratif secara konvensional. Upaya ini dilakukan melalui pemanfaatan perangkat analisis semiotik strukturalis yaitu dengan mendalami realsi antar makna simbol baik secara sintagmatis maupun paradigmatis.
\end{abstract}

Kata Kunci: semiotik, penerjemahan, simbol, sintagmatik, paradigmatik

\title{
Introduction
}

The term semiotics comes from the Greek root, semeion, which means 'sign.' Semiotics is referred to as the science of signs because it examines signs, uses of signs, and everything related to signs. Nonetheless, Hidayat (2010) states that semiotics cannot be called a field of science because it functions as an analytical tool or a way of breaking down a symptom. Consequently, many choose to call it an approach, and some simply use it as a method. These assumptions arise because semiotics has a cross disciplinary characteristic, and shares similarities with philosophy and logic. It is evident that semiotics has been used by various fields of science including architecture, medicine, cinematography, law, anthropology, literature, and most specifically linguistics. In essence, semiotic can explicitly be 
defined as the theory and analysis of various signs and their meaning (signification).

On the role of semiotics as a method in design research, Piliang(2010) writes that in the field of design, semiotics is used as a 'paradigm' in both 'reading' and 'creation' (creating). It happens because there is a tendency in the design discourse to see design objects as a language phenomenon, in which there is a sign, a message to be conveyed (message), rules that regulate (code) and the people involved as the subjects of language (audience, reader, user). In this regard, Christomy (2010) discusses the role of semiotics in cultural studies. He states that Saussure's view of signs can be imagined as a chess game, because each element on the chessboard must relate to the other elements. Every movement presupposes choice and contrast (semantics), and each forward motion presupposes linearity (syntax). Consequently, this view contributes significantly to cultural research because it provides an opportunity to reduce phenomena into explicit rules as grammar. So in the Saussurean view, the sign is synchronically governed by the paradigmatic aspect or a set of choice marks which are packaged in a hierarchical form. Another aspect is syntagmatic in which the signs taken from a set or paradigm can be combined with other paradigms by following the applicable rules. In addition to the views of Saussure, Christomy also reveals Peirce's semiotic role in cultural studies, which not only touches the concept of linearity but also the logic of space related to time or process.

Regarding the above phenomena, semiotics as the knowledge of signs have become an increasingly interesting interdisciplinary area of study. As such, semiotics can also be used as an approach, both structurally and pragmatically, for translation studies-particularly 
ones in which meanings are difficult to understand, including symbolic texts. As part of figurative language, symbolic texts have its own uniqueness because its literal meaning shows another figurative meaning that can only be understood through its literal meaning (Ricoeur, 1974). This also makes symbolic texts are difficult to translate into the target text (TT). In addition containing figurative meanings, the translation of religious texts, especially symbols, is also constrained by the literal dichotomy phenomenon - which the Biblical translators have faced since the time of the Roman Empire up to the present. On the translation of the Book of Revelation, for instance, (Bratcher \& Hatton, 1993) state that there are two contradictory concerns, namely whether the translators translate the symbolic text literally or otherwise interpret it to meet the needs of the target reader. In fact, the translators themselves often do not fully comprehend the meanings of these symbols.

Bassnett (2002) states that currently translation has increasingly adopted an interdisciplinary approach as an intertextual and intercultural transposition. For this reason, although translation activities are centered on linguistic activities, it is very appropriate if this study utilizes semiotics as an approach that explains the system or sign structure, sign process, and sign function. Therefore, this paper aims to uncover the role of semiotics in the translation of symbolic languages, especially in religious texts.

\section{Theories in Translation of Symbolic Texts}

\section{A. Translation Theory}

Translation theory can be defined as a general orientation for translators in making decisions when conducting translation activities. 
This involves the form of knowledge that the translators have in conducting translation activities - consisting of general principles to guidance, suggestions, and instructions. Yet in a more narrow sense, the theory of translation can be interpreted as an appropriate translation method for certain types of text. The use of different methods can also be interpreted as the application of different orientations. The choice is whether to refer to the source language or orient to the target language. Consequently, experts use a variety of different terms to refer to the separation of the two translation strategies such as formal and dynamic equivalence, domestication versus foreignization, and so on. However, the primary concept is actually still the same, namely regarding the orientation of strategies that reflect different theoretical approaches to translation.

In subsequent developments, the theoretical understanding of literal and free translation is not only considering the linguistic elements but is also increasingly developing with regard to cultural elements. This concept was raised by Venuti, known as domestication and foreignization. It emphasizes whether the Source Text (ST) is adapted into the culture of the Target Text (TT), or conversely the elements of foreign culture are retained. This is confirmed by ZareBehtash \& Firoozkoohi (2009), stating that since the Venuti era, translation strategies have adopted cultural aspects and ideology as factors that are taken into account in the translation process and also the effect of translation on the target audience and their culture. Therefore, in this case the separation of literal and free translation orientation not only pays attention to linguistic elements but also increasingly towards cultural considerations and target readers. 
Another figure who also discusses at length the different divisions of translation into two poles is Nida, by introducing the term formal equivalence and dynamic equivalence. According to Nida, formal equivalence can be interpreted as a strategy that focuses attention on the message itself, both at the level of form and content of the message. This is done by translators to provide insight in the form of lexical, grammatical, or textual structure of Source Language (SL). On the other hand, functional equality is centered on equal effects, namely in the sense that the relationship between the recipient of the message and the message itself must be at the level of the impression received by the recipient of the message in the source language (Nida, 2001). In contrast to Venuti who tends to adopt a literal strategy rather than dynamically, Nida prefers to struggle with functional equivalence that emphasizes reading aspects even though it does not ignore the accuracy and loyalty of SL. This is sharply criticized by (Newmark, 2001) who states that the tendency to apply functional equivalence results in the loss of the main meaning, especially the translation of biblical metaphor, which according to Nida is difficult for the target reader to understand.

\section{B. Dimensions of Meaning}

In general, it is certain that meaning plays an important role in the theory of translation. Without the theoretical explanation of meaning, it would be very difficult to understand the important issues in the theory of translation. According to Nida \& Taber (1974) meaning consists of three aspects, namely linguistic meaning, referential meaning, and emotive meaning. 
Linguistic meaning, also known as grammatical meaning, refer to the meaningful relationships between constituent parts in grammatical constructions namely words, phrases, and sentences. Consequently, it is noteworthy that phrases and sentences built from the same construction do not always share the same meanings. An example often used by Nida is the comparison between the four phrases of his car, his failure, his arrest and his goodness. The four phrases have the same structure, namely pronominal possessive (his) + noun. However, the relationship between the one with the noun that follows it is quite different in each phrase, namely 'he has a car', 'he failed', 'he was arrested' and 'he is good'. This understanding according to Nida implies that the four expressions actually have different meanings, namely A possesses B, A performs B, A is the goal of the action B, and B is the quality of $\mathrm{A}$.

Based on the above understanding, in order to eliminate the ambiguous impression on surface structures, a reconstruction of the inner structure is warranted-which experts call the 'kernel', referring to the basic structural elements of language that builds seemingly complicated surface structures. Regarding this, Nida \& Taber (1974) state that translators must agree to understand that languages have understanding at the kernel level to reveal surface structures that are immensely complex.

Nida \& Taber (1974) define referential meaning as the meaning of words as symbols that refer to objects, events, abstracts, and relations. In terms of figurative meaning, a word can have very different additional meanings in every important aspect with regard to a central meaning, in addition to having a central meaning and literal meaning that is quite close to the central meaning. This type of 
meaning cannot be directly related to the central meaning, and hence is known as figurative meaning. Yet Nida \& Taber (1974) state that both meanings can be mediated through components known as supplementary components. This additional component is purely conventional and is in the psychological realm. Considering that this component is arbitrary and conventional, its understanding is dependent on local, cultural, and language factors. One example used is taken from the Bible, Acts 2:17: "pour out my Spirit upon all flesh." In this connection, "flesh" is not interpreted according to its main meaning as an object which has a period. Rather, according to its figurative meaning, 'flesh' refers to objects that are truly differentnamely people or human beings.

On the other hand, emotive meaning, also known as connotative meaning, refers to the associations or emotional reactions to words and actions of communication (Nida \& Taber, 1974). The values involved in tracing emotive meanings such as taboos (positive and negative), vulgarities, obscenities, slang, long-windedness and so on. Assessment of emotive meaning in a cultural context can be done by analyzing the behavior of foreign speakers' responses to the use of certain words when studying foreign languages or mother tongue. In this regard, there is no standard method for measuring the connotative value of a word. However, one method considered the most relevant is offered by Osgood, Suci, and Tannenbaum, which uses matrices on a semantic scale of 1 to 10 . This is done by contrasting adjective pairs: good-bad, beautiful-ugly, strong-weak, light-dark, high-low, warmcold, and so on. 


\section{Semiotic Theory}

In general, semiotic theory is understood to be related to signs. Specifically, the relationship between signs is intended because there is no sign that is meaningful if it is not related to other signs. The meaning of the sign produced from the relationship of two elements (dyadic) is known as Saussure semiotics and the sign meaning produced from the relationship of three elements (triadic) is known as Peirce semiotics (Ratna, 2013). The following is an explanation of each model of relations between signs according to Saussure and Peirce.

\section{Saussure Semiotics}

Two elements that build a sign according to Saussure Semiotics are 'signified' and 'signifier.' The value of a sign is very dependent on its relationship with other signs in a system. For example, even though a sign in the form of a word 'tree' implies meaning on its own, but is very dependent on its relation to other words in a system such as 'bush'. In other words, a sign does not have an absolute value outside the attachment to the context. Figure 1 is a picture of the model of inter-sign relationships:

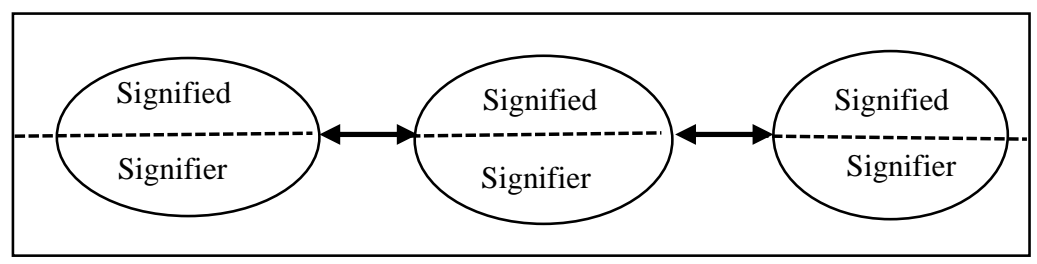

Figure 1. Inter-Sign Relationship Model According to Saussure (Source Saussure, 1983) 
Connectedly, Saussure's views on semiotic analysis specifically focuses the attention on three types of systemic relationships, namely signified and signifier, signs with all other elements in one system/code, and sign relationships with the elements surrounding it (Chandler, 2007). Furthermore, systemic relationships between signs can be described as syntagmatic relationships, namely those concerning position and paradigmatic, involving substitution or associative relations. Temporally, syntagmatic relationships refer to intertextual relationships with markers that are present in the text, while paradigmatic relationships refer to intertextual relationships with markers that are absent from the text. Such an approach is known to be very good to be used as an approach to textual analysis that focuses on structural analysis.

Some analytical tools in the paradigmatic dimension include replacement tests (the commutation test), opposition, markedness, deconstruction, and alignment. Table 1 shows the formulation of paradigmatic analysis tools:

Table 1. Formulation of Paradigmatic Analysis Tools

\begin{tabular}{|l|l|l|}
\hline \multicolumn{1}{|c|}{ Type of Analysis } & Understanding/Definition & \multicolumn{1}{c|}{ Rules } \\
\hline $\begin{array}{l}\text { The commutation } \\
\text { test }\end{array}$ & Identify distinctive signifier & - A particular \\
& and define their significance & $\begin{array}{l}\text { signifier in a text is } \\
\text { selected } \\
\text { - Considering the } \\
\text { alternative to the } \\
\text { selected signifier } \\
\end{array}$ \\
& & $\begin{array}{l}\text { Evaluating the } \\
\text { effect of each } \\
\text { substitution in terms } \\
\text { of how this might } \\
\text { affect the sense } \\
\text { made of the sign }\end{array}$ \\
& & $\begin{array}{l}\text { Pairing binary } \\
\text { signifiers }\end{array}$ \\
\hline Opposition & Use binarism to express & \\
& & \\
\hline
\end{tabular}




\begin{tabular}{|c|c|c|}
\hline Type of Analysis & Understanding/Definition & Rules \\
\hline & meaning & $\begin{array}{l}\text { - Determine and } \\
\text { evaluate the type of } \\
\text { oppositions that } \\
\text { consist of } \\
\text { opposition (digital: } \\
\text { 'either/or') and } \\
\text { antonyms } \\
\text { (analogue: 'more- } \\
\text { atau-less) }\end{array}$ \\
\hline Markedness & $\begin{array}{l}\text { The linguistic system is built } \\
\text { on opposition from two } \\
\text { logical contradictions: the } \\
\text { presence of attributes } \\
\text { (marked) in contraposition } \\
\text { to its absence (unmarked) }\end{array}$ & $\begin{array}{l}\text { - Juxtaposing marked } \\
\text { and unmarked } \\
\text { signifiers } \\
\text { - Marked consisted of } \\
\text { formal marking and } \\
\text { distributional } \\
\text { marking }\end{array}$ \\
\hline Alignment & $\begin{array}{l}\text { Opposition is not fixed, } \\
\text { therefore paradigmatic } \\
\text { analysis can be done based } \\
\text { on correlation and analogy }\end{array}$ & $\begin{array}{l}\text { Pairing and analyzing } \\
\text { signifiers is not only } \\
\text { based on opposition, } \\
\text { but also correlations } \\
\text { and analogies }\end{array}$ \\
\hline
\end{tabular}

(Source: Chandler, 2007)

The syntagmatic analysis of the text, both verbal and nonverbal, involves an analysis of the structure and relations between its parts. Structuralism semiotics attempt to identify basic constituent segments in the text, namely the syntagma. The study of syntagmatic relationships reveals text conventions. The use of certain syntagmatic structures in the text has an influence on meaning. Some syntagmatic analysis tools include spatial relations, sequential relations and structural reduction.

Table 2. Formulation of Syntagmatic Analysis Tools

\begin{tabular}{|l|l|l|}
\hline \multicolumn{1}{|c|}{$\begin{array}{c}\text { Type of } \\
\text { Analysis }\end{array}$} & \multicolumn{1}{c|}{ Understanding/Definition } & \multicolumn{1}{c|}{ Rule } \\
\hline $\begin{array}{l}\text { Spatial } \\
\text { relations }\end{array}$ & $\begin{array}{l}\text { Spatial syntagmatic relations } \\
\text { include: } \\
-\quad \text { above/bellow; }\end{array}$ & $\begin{array}{l}\text { Mapping signifiers } \\
\text { based on the type of } \\
\text { spatial relations }\end{array}$ \\
\hline
\end{tabular}




\begin{tabular}{|c|c|c|}
\hline $\begin{array}{c}\text { Type of } \\
\text { Analysis }\end{array}$ & Understanding/Definition & Rule \\
\hline & $\begin{array}{ll}- & \text { in front/behind; } \\
- & \text { close/distant; } \\
- & \text { left/right; } \\
- & \text { north/south/east/west; } \\
- & \text { inside/outside (or } \\
& \text { center/periphery) }\end{array}$ & \\
\hline $\begin{array}{l}\text { Sequential } \\
\text { Relations }\end{array}$ & $\begin{array}{l}\text { The types of narrative } \\
\text { relationships that occur at the } \\
\text { beginning and end or 'chain' } \\
\text { events that lead to the } \\
\text { beginning, middle, and end of } \\
\text { a story }\end{array}$ & $\begin{array}{l}\text { Mapping signifiers } \\
\text { based on the type of } \\
\text { narrative relations }\end{array}$ \\
\hline
\end{tabular}

(Source: Chandler, 2007)

\section{E. Peircean Semiotics}

In contrast to Saussure, Peirce (Zoest, 1993) states that meaning is obtained by finding the relationship between the actual sign that is representamen $(\mathrm{R})$, what is referred to is object $(\mathrm{O})$, and new signs called interpretan (I) . $\mathrm{R}$ is a part of a sign that can be perceived physically or mentally which refers to something that it represents $(\mathrm{O})$ and $I$ is part of a process that interprets the relationship between $\mathrm{R}$ and O. Next is Peirce's model of three-element relations as illustrated by (Eco, 1976):

\section{Interpretant (I)}

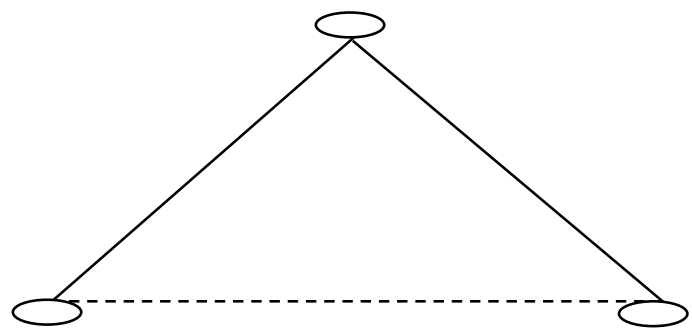

Representamen (R)

Object (O)

Figure 2. Relationship Model of the Three Elements of Signs According to Peirce 
In accordance with the above model, the three elements play equaly important roles to fulfill the requirements as a sign. Sign is the unit of what is represented (object), how it is represented (representamen) and how it is interpreted (interpretant). The three interactions are known as 'semeiosis' or semiosis.

As a triadic, $\mathrm{R}$ consists of qualisigns (representamen which are signs of a trait; for example, red or hot). Then, sinsigns (representamen, which are signs based on appearance in reality or type of sign that utilize an event or object as a vehicle sign), for example, a scream can mean pain, happiness or shock. Furthermore, legisigns (representamen which are signs on the basis of a generally accepted regulation, a convention, a code, for example such as traffic signs, handshake movements, etc.). The second trichotomy, namely $\mathrm{O}$, consists of icons, index, and symbol. Peirce assumes that the second trichotomy is the most fundamental. The third trichotomy, namely interpretant produces rheme, disisigns, and arguments. According to (Cobley \& Jansz, 1999) rheme is a sign interpreted as a possibility, for example, concepts. On the other hand, disisigns or dicents are signs that are interpreted as a fact, for example, descriptive arguments. While arguments are signs that are interpreted as a reason, for example, propositions or suggestions.

Peirce further reveals that the meaning of a representation is representation itself, in the sense that the initial interpretation can be reinterpreted so that a signified can also take on the role of a signifier. This thinking is manifested in a figure known as continuous interpretation: 


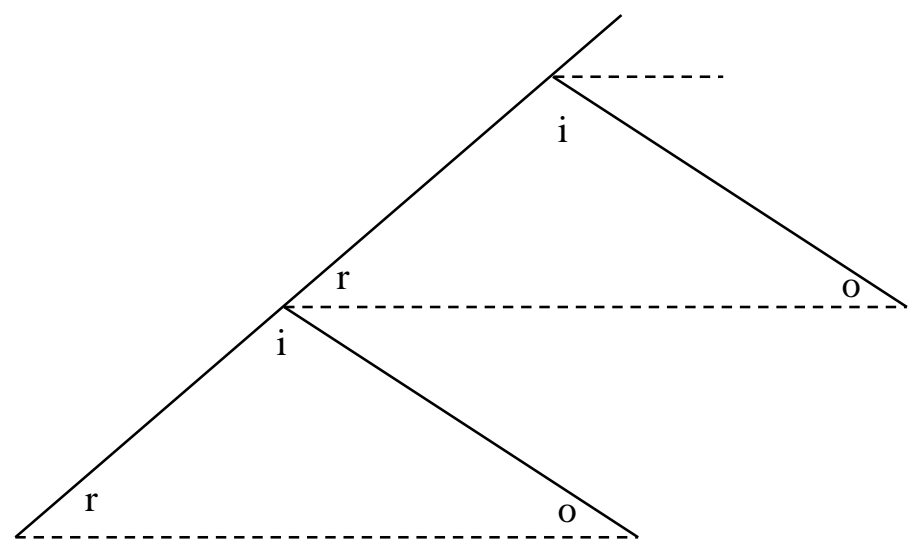

Figure 3. Peirce's Continuous Interpretation

(Source: Peirce, 1931)

In this sense, Christomy(2010) based on the understanding of (Zoest, 1993), asserts this continuous interpretation as something that was quite "frightening" because it did not rule out the possibility that interpretation could wander everywhere. Efforts should be made to prevent this. In making cartoons for example, those involved in it, made structural combinations between visual signs and verbal signs. This combination inevitably forms a new, narrower interpretation.

From the above explanation, it can be surmised that the fundamental difference between Saussure's and Peirce's versions of semiotics lies in the concept of sign meaning, which is found based on the relationship between one sign and another sign. A relatively static structure on the semiotic version of Saussure and a very dynamic interpretation process in the semiotic version of Peirce is known as dialogical thought. 


\section{Methods}

The source of the data in this study is an example of analysis of symbol translation, taken from six versions of the Bible based on the classification of literal translations and free translations. Included in the Bible literal translations that embrace the ideology of foreignization are: 1. Perjanjian Baru Interlinear dan Konkordansi (PBIK) (Sutanto, 2010), 2. Jay Green's Literal Translation (JGLT) (Green, 1985), and 3. Indonesian Literal Translation (ILT) (Bangsa, 2008). While those included in the free translation Bible by adhering to the domestication ideology are: 1. Good News Bible (GNB) and Bahasa Indonesia Masa Kini (BIMK) (Indonesia, 2010), 2. Terjemahan Sederhana Indonesia (TSI) (Kita, 2014), and 3. Bahasa Indonesia Sederhana (BISD) (Indonesia, 2003). The example of the analysis intended is the analysis of the translation of the symbol 'blood' from the six versions using a qualitative descriptive method. This method was chosen to describe and interpret the data in the form of an example of symbolic text translation analysis in order to uncover the attitudes and perspective about the role of semiotic science in the translation of religious texts.

The symbol referred to in this study is a verbal symbol in the form of text contained in the Christian Scriptures, called the Bible, which consists of Old Testament (OT) and New Testament (NT). More specifically, the intended symbol of "blood" is the symbol found in the last book of the NT, which the Book of Revelation. Verbal symbols are subtypes of symbols consisting of verbal symbols, graphic symbols and other pictorial symbols such as logos or trademarks, and flags. The symbols found in the scriptural texts are also known as religious 
symbols. This term is used to describe the use of symbols by certain religions for various purposes.

There are two stages of translation analysis on symbolic language carried out in this study, referring to the classification of meanings put forth by Nida (1964), namely the search for linguistic meanings or known as grammatical meaning and followed by the search for reference meaning or referential meaning. The first step is to determine the grammatical meaning of symbols by reconstructing structures in symbols that many experts refer to as 'kernel', which is the basic element of language structures that build surface structures that often seem complicated or even ambiguous. The second step is the focus in the analysis process, namely the determination of the referential meaning of the symbol, which in this case has no similarities, analogies, or factual relations with the designated object. The second stage is carried out by utilizing semiotic analysis, which is focused on functional structural relationships in the signing system. Furthermore, the results of the analysis steps above are compared to see the accuracy of the translation products, which in this case uncover the semiotic role in revealing the meanings referred to in the process of translation.

\section{Result and Discussion}

Based on the model of the relationship of three sign elements, which according to Peirce consists of representamen, objects, and interpretant, symbols in the text can be classified as representamen-something that is sensory or material. In this case, the representamen functions as a representative of symbol in the text. Its presence arouses the interpretant, which in turn HERITAGE OF NUSANTARA : 
acts to interpret the relationship between the representamen and the object it represents. If the subject matter is the translation of verbal symbols, namely the 'blood' symbol, then figure 4 is an example that can describe the role of representamen as a representation of the symbol in the text:

\section{Interpretant}

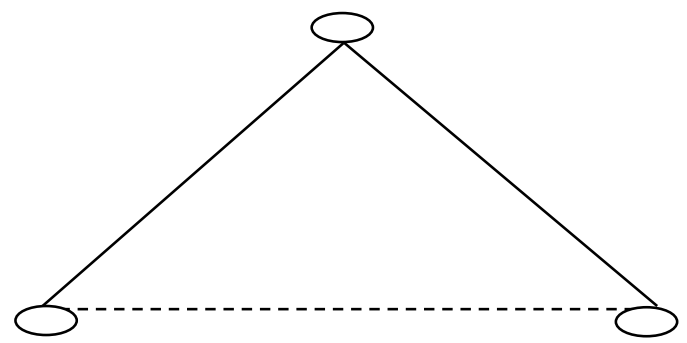

Representamen (Legisign)

haima, blood, darah, mati, kematian

Object

Figure 4. The Presence of 'Blood' Symbol in Religious Text

In the Jay Green's Literal Translation version (JGLT) which is the Source Text (ST) of the Indonesian Literal Translation (ILT) version, the 'blood' symbol is present as 'blood' in the phrase 'the blood of Him'. Meanwhile, in ILT the Target Text (TT) of JGLT that is the symbol of 'blood' presents as 'His blood', 'Your blood' and 'the blood of the Lamb'. On the other hand, in the free translation version of Good News Bible (GNB), which is the ST of Bahasa Indonesia Masa Kini (BIMK), the symbol 'blood' appears as 'death' in the phrase 'sacrificial death' and also 'the blood of the Lamb'. In contrary, the BIMK that is the TT of GNB the 'blood' symbol appears as 'His death', 'Your death' and 'the blood of the Lamb'. Another version, namely Perjanjanjian Baru Interlinear dan Konkordansi (PBIK) that translates directly the word from the original Greek language, the 
'blood' symbol appears as 'haima' in the ST and 'His blood', 'Your blood' and 'the blood of the Lamb' in TT. In addition, there are also other versions in free translation, namely Terjemahan Sederhana Indonesia (TSI) and Bahasa Indonesia Sederhana (BISD), which emerge the blood symbol as 'His blood' in TSI and 'die' in BISD. The two versions do not clearly mention the ST referred to, but only emphasize that both are translated as freestyle.

However, it should be underlined that what can be called the Source Language (SL) of the Bible is Hebrew for the Old Testament (OT) and Greek for the New Testament (NT). The entire results of the current Bible translation including those used as sources of data in this study can be said to be the Target Language (TL) only translated with a different ideology, literally or freely. In this connection, the source language of the symbol 'blood' is actually 'haima', which is the Greek language as written in PBIK.

The data above shows that the symbol of 'blood' in the biblical text appears in various representamen or also known more specifically as legisign, namely the type of representamen that appears on the basis of common rules, or a convention or code. If tabulated, as seen in table 3 , it is clear that the appearance of the 'blood' legisign can be classified into two groups, which remain as 'blood', or as 'die' or as 'death'. Connectedly, the Ensiklopedia Sabda affirms that indeed there has been a controversy over the appearance of the 'blood' symbol in the biblical texts, in terms of whether this symbol refers to death or life. Regarding this, Browning (1996) argues that in Hebrew thought 'blood' refers to the place or center of life, or even identified with life itself. Therefore, 'blood' has a fundamental role in the sacrificial offering in the religious life of the Hebrew community. 
Table 3. Tabulation on the Occurrence of 'Blood' Legisign in Various Versions of Literal and Free Translation

\begin{tabular}{|c|c|c|c|c|c|c|}
\hline \multicolumn{7}{|c|}{ 'Blood' Legisign } \\
\hline \multicolumn{3}{|c|}{ Literal Versions } & \multicolumn{4}{|c|}{ Free Versions } \\
\hline PBIK & JGLT & ILT & GNB & BIMK & TSI & BISD \\
\hline $\begin{array}{l}\text { darah- } \\
\text { Nya } \\
(1: 5)\end{array}$ & $\begin{array}{c}\text { the } \\
\text { blood } \\
\text { of Him } \\
(1: 5)\end{array}$ & $\begin{array}{l}\text { darah- } \\
\text { Nya } \\
(1: 5)\end{array}$ & $\begin{array}{c}\text { his } \\
\text { sacrificial } \\
\text { death } \\
(1: 5)\end{array}$ & $\begin{array}{c}\text { dengan } \\
\text { kematian- } \\
\text { Nya } \\
(1: 5)\end{array}$ & $\begin{array}{c}\text { melalui } \\
\text { darah- } \\
\text { Nya } \\
(1: 5)\end{array}$ & $\begin{array}{c}\text { mati untuk } \\
\text { membebaskan } \\
\text { kita } \\
(1: 5)\end{array}$ \\
\hline $\begin{array}{c}\text { dengan } \\
\text { darahMu } \\
(5: 9)\end{array}$ & $\begin{array}{l}\text { by the } \\
\text { blood } \\
\text { of You } \\
(5: 9)\end{array}$ & $\begin{array}{c}\text { dengan } \\
\text { darah- } \\
\mathrm{Mu} \\
(5: 9)\end{array}$ & $\begin{array}{c}\text { your } \\
\text { sacrificial } \\
\text { death } \\
(5: 9)\end{array}$ & $\begin{array}{c}\text { dengan } \\
\text { kematian- } \\
\mathrm{Mu} \\
(5: 9)\end{array}$ & $\begin{array}{c}\text { dengan } \\
\text { darah- } \\
\mathrm{Mu} \\
(5: 9)\end{array}$ & $\begin{array}{c}\text { Dengan } \\
\text { kematian-Mu } \\
(5: 9)\end{array}$ \\
\hline $\begin{array}{c}\text { di dalam } \\
\text { darah } \\
\text { Anak } \\
\text { Domba } \\
(7: 14)\end{array}$ & $\begin{array}{l}\text { in the } \\
\text { blood } \\
\text { of the } \\
\text { Lamb } \\
(7: 14)\end{array}$ & $\begin{array}{c}\text { dengan } \\
\text { darah } \\
\text { Anak } \\
\text { Domba } \\
(7: 14)\end{array}$ & $\begin{array}{c}\text { with the } \\
\text { blood of } \\
\text { the Lamb } \\
(7: 14)\end{array}$ & $\begin{array}{c}\text { dengan } \\
\text { darah } \\
\text { Anak } \\
\text { Domba } \\
\text { itu } \\
(7: 14)\end{array}$ & $\begin{array}{c}\text { dengan } \\
\text { darah } \\
\text { Anak } \\
\text { Domba } \\
(7: 14)\end{array}$ & $\begin{array}{c}\text { di dalam } \\
\text { darah Anak } \\
\text { Domba } \\
(7: 14)\end{array}$ \\
\hline
\end{tabular}

Table 3 illustrates the inconsistencies on the form of 'blood' legisign in the free translation texts. For this reason, it is necessary to do an in-depth analysis of the reference meaning of the 'blood' symbol, especially in the code of redemption. Regarding this, the 'blood' symbol is mentioned 19 times out of a total of 22 chapters contained in the book of Revelation (Erfiani, 2018). Upon further examination, however, not all symbols refer to the same thing. As such, to narrow the scope of the discussion, the analysis should be focused on legisigns that have the same code. This is in line with the assertion of (Chandler, 2007) that signs are actually arranged based on codes that describe their position and selection in certain contexts. In fact, there are three codes that limit the scope of each of the 19 symbols; namely redemption, judgment or vengeance, God's wrath, and the signs of the last days. In this case, only legisigns that have a redemption code are 
discussed as examples of analysis in this study and which also appear in several verses as found in the tabulation of table 3 above.

The representamen or legisign of 'blood' clearly refers to an object, which in the figurative realm can be very different from the legisign itself. Expressly, the sign does not have a physical relationship with the object referred to in the classification of the sign made by Peirce referred to as a symbol. The relationship between legisign and the object referred to is only based on an agreement that is uncertain or purely conventional. Regarding this, Nida \& Taber (1974) state that a word besides having a central meaning and literal meaning that is quite close to the central meaning can also have additional meanings that are very different in every important aspect with a central meaning. But it needs to be emphasized that the meaning of this type can be mediated through additional components or also called 'supplementary components' that are purely conventional. It is also stated that this additional component is in the psychological realm that is arbitrary so that its understanding depends heavily on local cultural and language factors.

To find out the reference or referential meaning of the 'blood' legisign, it can stand first on linguistic or grammatical meaning. The appearance of the 'blood' legisign in Table 3 is structurally a form of ownership construction that can be interpreted more broadly than just the blood belonging to the Lamb. In other words, the translation does not come from a normal possessive construction, namely Lamb's blood but from the ST 'the blood of You', 'the blood of Him' or 'the blood of the Lamb'. If it is reconstructed based on the kernel or the basic structure underlying the phrase above, it can be interpreted as 'the Lamb gives His blood to us or to them or the Lamb gives us or them 
blood. In the case, the subject is not only the owner but there is an active role of the subject namely the action of 'giving'.

Furthermore, to understand the representative meaning or reference of the 'blood' legisign, which is arbitrary or not directly related to the object, semiotic analysis can be carried out by utilizing the relationship between the signs. Specifically, the analysis of the relationships between signs in the semiotic domain is used to reveal the additional meaning or supplementary component that can mediate between legisign and the object it represents. This type of analysis focuses on systemic relationships between signs, namely signified with signifier, signs with all the other elements in a system or code, and sign relationships with the elements surrounding it. The relationship pattern can be described as a syntagmatic relationship, which involves the position or intertextual relationship to the signifier present in the text and the paradigmatic relationship that is related to substitution or associative or intertextual relationships to signifers that are absent from the text.

In terms of Syntagmatic patterns, the symbol of 'blood' found in the Book of Revelation has a relationship with several other symbols in the same Book, which isdescribed as the relation of markers to other elements present in the texts. For this reason, it is necessary to codify the signifiers that have the value of coherence or homogeneity, which in this case leads to the symbol 'blood' in the redemption code. Some of these markers are found in Revelation 1 verse 5, Revelation 1 verse 7, Revelation 1 verse 18, Revelation 5 verse 9, Revelation 5 verse 18, and Revelation 7 verse 14. Once mapped, an illustration of the relationships between symbols in the redemption code is obtained based on sequential relationship patterns. This pattern governs symbols 
based on the type of narrative relationship that presents a chain of events in the story of redemption. This mapping is shown in Figure 5.

Codification is a step taken to examine relations between symbols based on the principles of coherence, homogeneity, and systematization of signs in a text. (Turner, 1992) states that this step serves to simplify phenomena that are useful for making it easier to understand text messages. In this case, the symbol 'blood', which is observed in a syntagmatic way is related to several key symbols in the Book of Revelation. By looking at the relationship between these symbols the meaning contained in the symbol 'blood' can be revealed to the surface through the interrelationships between symbols in the same code, namely redemption

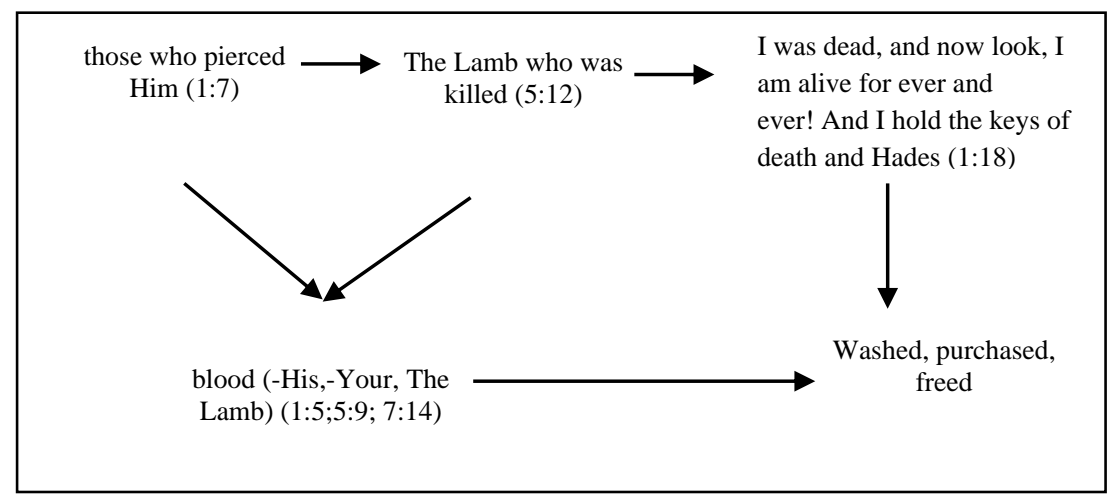

Figure 5. Inter-symbol relations in the Redemption Code (Erfiani, 2018)

Figure 5 shows a series of events, which begins with the piercing of an entity called Him or pronominal Him and $\mathrm{Mu}$ in another chapter, which is then revealed as the Lamb of God. In this case, the verb 'pierced' can be said to be synonymous with 'killed' even in different forms (active and passive). This shows that there has been an 
event of bloodshed, which resulted in the death of the entity called the Lamb of God. However, it should be noted that the series of events does not end at the death phase but is followed by life or resurrection. This shows the success of the mission with the sign of the success of the entity in seizing the key to the kingdom of death. The estuary of all events is the redemptive mission itself, namely to wash, to buy, and to whiten the people who are called loved ones (1:5) or tribes (5: 9) from their sins and transgressions.

If explored more deeply, the whole series of events in the 'redemption' code in fact boils down to the purpose of washing, buying and whitening those who are called loved ones (1: 5), ethnicity (5:9), and people who come out of great tribulation (7:14). The following is a display of some of these verses in full which were taken from Jay Green's Literal Translation (JGLT) as source texts (ST) and Indonesian Literal Translation (ILT) as target texts (TT):

To him loving us, and having washed us from the sins of us by the blood of Him (JGLT, 1:5)(Green, 1985)

Bagi Dia yang telah mengasihi kita dan telah membasuh kita dari dosa-dosa kita dengan darah-Nya (ILT, 1:5)(Kita, 2014)

....because you were slain and purchased the God of us by the blood of You out of every tribe and tongue and people and nation....(JGLT, 5:9)(Green, 1985) ....sebab Engkau sudah disembelih dan dengan darah-Mu Engkau sudah membeli kami bagi Elohim, dari setiap suku dan bahsa dan kaum dan bangsa, ....(ILT, 5:9)(Kita, 2014)

....These are those coming out of the affliction great, and they washed the robes of them, and whitened them in the blood of the Lamb (JGLT, 7:14)(Green, 1985)

...." Mereka ini adalah orang-orang yang keluar dari kesukaran besar dan mereka telah mencuci jubbah panjang mereka dan memutihkan jubbah panjangnya dengan darah Anak Domba" (ILT, 7:14)(Kita, 2014) 
The result of this syntagmatic analysis is in line with the linguistic meaning or grammatical meaning produced through the 'kernel' in the phrases of 'the blood of Him', 'the blood of You' and 'the blood of the Lamb', that the agent, in this case the Lamb gave His blood for a mission, that is to wash, to buy, and to whiten those who are called His beloved ones.

Paradigmatic analysis, on the other hand, can be done by applying an alignment pattern that can later produce analogous relations and correlation between signs or legisigns found in the Book of Revelation with other books in the Bible. These books are Genesis and Leviticus in the Old Testament (OT) and Romans in the New Testament (NT). Some chapters in the Books, chosen based on the code of redemption, are Genesis chapter 2 verses 16 to 17, Romans chapter 6 verse 23, Leviticus chapter 17 verses 10 to 12 and Leviticus chapter 1 verses 10 to 11 .

The following depiction (Figure 6) show the map of the relation of the verses which is based on the pattern of analogy relations. To further clarify the paradigmatic relationship between verses about 'blood' in the redemption code, which is connected by analogy, the following is a complete quote of those verses, taken from Jay Green's Literal Translation (JGLT) as source texts (ST) and Indonesian Literal Translation (ILT) ) as target texts (TT):

And Jehovah God commanded the man, saying. You may freely eat of every tree in the garden; but of the Tree of Knowledge of Good and Evil you may not eat, for in the day that you eat of it, you shall surely die (JGLT, Gen. 2:16-17)(Green, 1985)

Selanjutnya YAHWEH, Elohim memberi perintah kepada manusia, "Engkau boleh makan buah dari pohon manapun yang ada didalam taman ini, tetapi pohon pengetahuan tentang hal yang baik dan jahat jangan kamu makan buahnya, karena pada hari engkau 
The Role of Semiotics ....

memakannya, engkau pasti akan mati (ILT, Kej. 2:16-17)(Kita, 2014)

For the wages of sin is death; but the free gift of God is everlasting life in Christ Jesus our Lord (JGLT, Rm. 6:23)(Green, 1985)

Sebab upah dosa ialah maut, tetapi karunia Elohim ialah hidup yang kekal di dalam Kristus Yesus Tuhan kita (ILT, Rm. 6:23)(Kita, 2014)

For the life of the flesh is in the blood and I have given it to you on the altar, to make atonement for your souls; for it is the blood which makes atonement for the soul (JGLT, Lev. 17:11)(Green, 1985)

Sebab, kehidupan tubuh ada di dalam darah, dan Aku telah memberikan darahnya kepadamu di atas mezbah itu untuk mengadakan penebusan bagi kehidupanmu, sebab darah itulah yang mengadakan penebusan bagi kehidupan (ILT, Im. 17:11)(Kita, 2014)

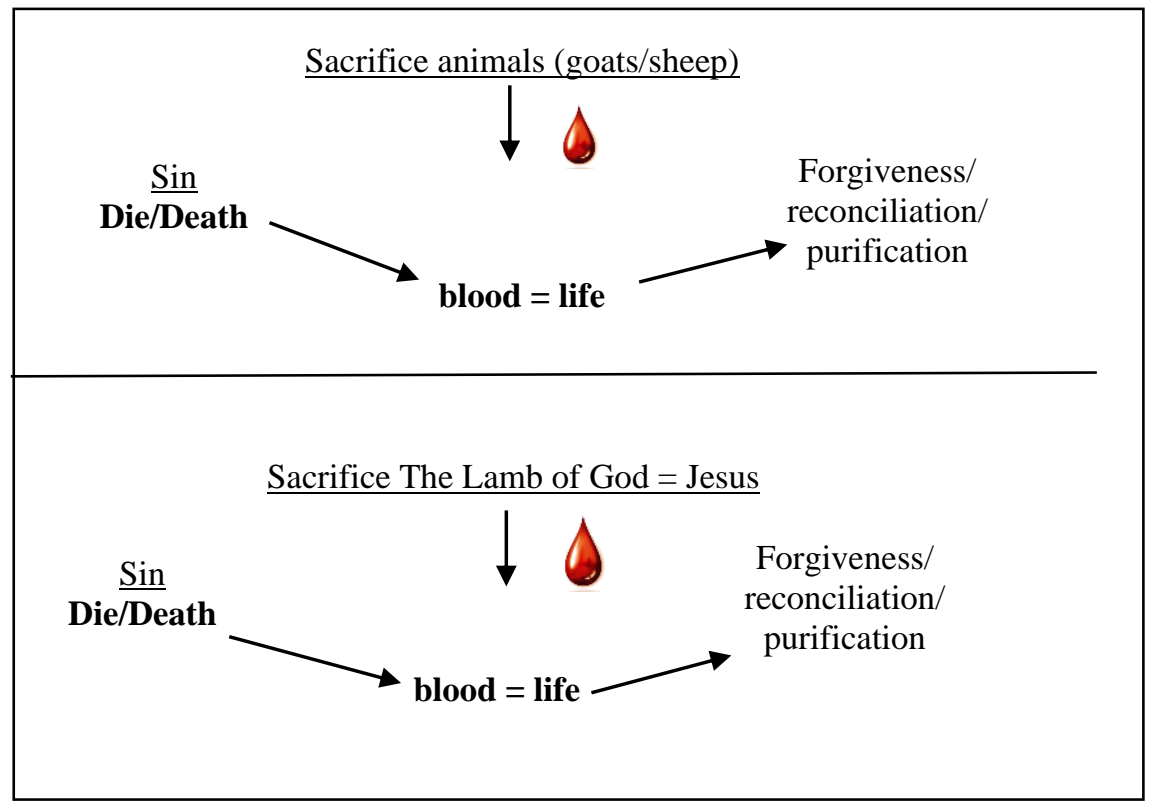

Figure 6. Analogy Relations of Blood Shedding Event in OT and NT

(Erfiani, 2018)

In general, figure 6 shows that the two events, namely animal sacrifice in the OT and the sacrifice of the Lamb of God known as the 
entity Jesus, has an analogical relationship. Expressly, it can be surmised that the legisign 'blood' in NT has a relationship with legisign 'blood' found in the OT, which states that 'blood' is identical to life which serves to give life to beings in this case humans who die because of sin. So 'blood' in the event of redemption symbolizes life because it is said that the life of a living being is in his blood. Therefore, 'blood' is given/poured out as a means of reconciliation to give life to beings who have died from sin.

The results of the analysis, according to both patterns of syntagmatic and paradigmatic relationships, show the same results that the 'blood' legisign refers to the same object, namely 'life'. This is also in line with the results of the grammatical analysis which states that 'blood' is not only possessed but there is an active action by the owner to give or pour it out as a means of purification or redemption. The understanding of the results of this analysis can be used as a basis for understanding the figurative meaning of 'blood' in which the relationship between legisign and the object referred to is only based on a purely conventional agreement. In accordance to the assertion of Nida \& Taber (1974), there is a supplementary component that mediates both so that there is an understanding between the central meaning, the literal meaning and also its additional meaning. Literally, 'blood' can be interpreted as fluid, plasma, erythrocytes, leukocytes, and life support. On the other hand, figuratively, 'blood' can be understood as a means of cleansing, washing, and also a means to redeem. Based on the results of semiotic analysis, additional components can be obtained which can connect the two conventionally, that 'blood' can give life to the death caused by sin. 
If reviewed based on the relationship of the three sign elements made by Peirce, which consists of representamen (R) (in this case legisign), object $(\mathrm{O})$, and interpretant (I), then the following is an illustration of the 'blood' symbol along with the explanation:
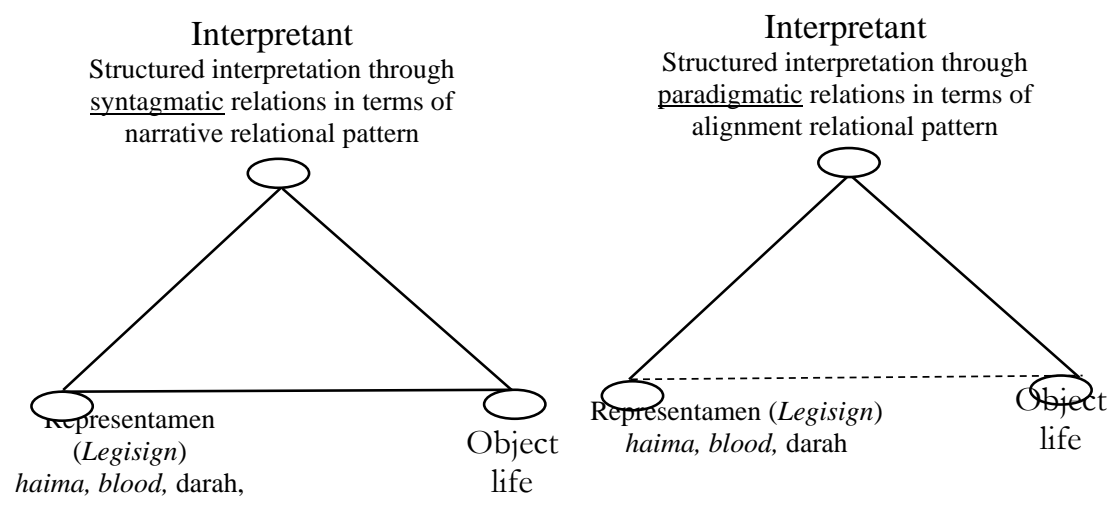

Figure 7. Analysis on 'Blood' Symbol According to Peirce's Trichotomy

The actual sign, or ( $\mathrm{R}$ ) in the picture above is 'blood' or 'darah' or 'haima', or 'mati' or 'kematian' are symbols or legisigns that appears in the text of various versions of translation. Meanwhile, what is referred to $(\mathrm{O})$ from the results of the analysis is 'life'. In accordance with the explanation above, the object is generated from the interpretation (I) of the relationship between $\mathrm{R}$ and $\mathrm{O}$ through structured interpretation both with syntagmatic and paradigmatic patterns of relationship.

The figure 7 and explanation above indicate that the meaning referred to by the symbol 'blood' is life and not death. This is revealed from semiotic analysis, namely structured interpretation with narrative patterns in syntagmatic relations and patterns of alignment in paradigmatic relations, which then reveals additional meanings that 
connect $\mathrm{R}$ and $\mathrm{O}$, conventionally or in agreement. This semiotic analysis also reveals that there has been a misinterpretation made by the translator of the free translation version in translating 'haima' or 'blood' in ST into 'death' in TT. If described in the process of semiosis, the representamen (in this case the legisign) that appears on the ST undergo the process of interpretation by the translator so as to produce a new sign, which then appears as representament on the TT. However, it should be noted that the reference meanings that is 'die' or 'death', which is placed as representamen or ligisign in TT do not reflect the true meaning of the symbol, namely 'life'.

As revealed by Christomy (2010) based on Zoest's understanding that interpretations need to be limited so that they do not become 'wild' and uncontrolled. Connoisseurs of contemporary paintings need to get an explanation from curators, critics, and even from the painter himself to narrow the interpretation that emerges about the observed painting. Likewise, cartoon makers limit the interpretation of readers or viewers by combining visual signs with verbal signs. This concept also underpins the process of interpreting a symbol in translation activities. In this case, a translator needs to limit his interpretation of a representamen, in this case legisign, which is in the form of verbal symbols by observing the relations between signs, both syntagmatic and paradigmatic. Through a structured interpretation process carried out by the translator, the interpretation sequence seems to be interrupted through the emergence of additional meanings that can connect the representamen (legisign) with the object referred to conventionally. 


\section{Conclusion}

The analysis shows that semiotics that has interdisciplinary reach, and is proven to play a role in the analysis of translation symbolic language - in this case is religious text. This role is clearly seen in the effort to express the dimensions of referential meaning or conceptual symbols through the analysis of structured interpretations of relationships between symbols in syntagmatic and paradigmatic patterns. This interrelation pattern, namely the narrative on syntagmatics and the alignment on paradigmatic, successfully expresses additional meaning, which connects literal and figurative meanings conventionally.

In this case, semiotic analysis succeeded in revealing the misinterpretation carried out by the translator of free translation version who translated 'haima' or 'blood' into 'death'. The occurrence of 'kematian', 'mati', or 'death' in some free versions on the Bible such as Good News Bible (GNB), Bahasa Indonesia Masa Kini (BIMK) and Bahasa Indonesia Sederhana (BISD) can be considered as translator's misinterpretation in understanding the meaning of 'blood' in the process of translating religious texts. This finding is very important to be discussed and examined considering that the free translation version is often used as a companion reading in understanding literal translation texts, which are quite difficult to understand, especially when it comes to religious symbolic language.

A recommendation to stem from in this study is that translators in translating freely or also known as thought for thought translation, especially for symbolic texts, should be careful not to get caught in the fabric of interpretants that can form interpretations without limits. To 
that end, a series of interpretations can be narrowed to certain segments by reviewing the systemic relationship between signs that are in one code both syntagmatically and paradigmatically. This process, which results in limited referential meanings, can be confirmed by linguistic or grammatical meanings so that they become a unified whole meaning and avoid prolonged misinterpretations.

\section{References}

Yayasan Lentera Bangsa (2008). Kitab Suci Indonesian Literal Translation. Yayasan Lentera Bangsa.

Bassnett, S. (2002). Translation Studies. Routledge.

Bratcher, R. G., \& Hatton, H. . (1993). A Handbook on the Revelation to John. United Bible Societies.

Browning, W. R. F. (1996). Kamus Alkitab: A Dictionary of the Bible. PT BPK Gunung Mulia.

Chandler, D. D. (2007). Semiotics: the basics. Basics (Routledge (Firm), xviii, 307 p. https://doi.org/10.1016/S03782166(02)00176-5

Christomy, T. (2010). Peircean dan Kajian Budaya. In T. Christomy \& U. Yuwono (Eds.), Semiotika Budaya. Kampus UI: Pusat Penelitian Kemasyarakatan dan Budaya.

Cobley, P., \& Jansz, L. (1999). Introducing Semiotics. Icon Books Ltd.

Eco, U. (1976). A Theory of Semiotics. Macmillan.

Erfiani, D. (2018). Apokaliptik: Menyingkap Makna Simbol Kitab Wahyu dari Sudut Pandang Penerjemahan. Pustaka Pelajar.

Green, J. P. (1985). The Interlinear Bible Hebrew-Greek-English with Strong Cncordance Numbers Above Each Word. Henrickson Publishers Marketing, LLC.

Hidayat, R. (2010). Semiotik dan Bidang Ilmu. In Semiotika Budaya. Kampus UI: Pusat Penelitian Kemasyarakatan dan Budaya. 
Lembaga Alkitab Indonesia (2003). Perjanjian Baru dalam Bahasa Indonesia Sederhana. Lembaga Alkitab Indonesia.

Lembaga Alkitab Indonesia (2010). Alkitab Kabar Baik - Good News Bible dalam Bahasa Indonesia dan Bahasa Inggris Masa Kini. Lembaga Alkitab Indonesia.

Yayasan Alkitab Bahasa Kita (2014). Alkitab Perjanjian Baru dalam Terjemahan Sederhana Indonesia. ANDI.

Newmark, P. (2001). Approaches to Translation. Shanghai Foreign Language Education Press.

Nida, E. (1964). Towards a Science of Translating with Special Reference to Principles and Procedures Involved in Bible Translating. E.J. Brill.

Nida, E. (2001). Context in Translating. John Benjamins Publishing Company.

Nida, E. ., \& Taber, C. R. (1974). The Theory and Practice of Translation. E.J. Brill.

Piliang, Y. A. (2010). Semiotika Sebagai Metode dalam Penelitian Desain. In T. Christomy \& U. Yuwono (Eds.), Semiotika Budaya. Pusat Penelitian Kemasyarakatan dan Budaya.

Ratna, N. K. (2013). Glosarium:1.250 Entri Kajian Sastra, Seni, dan Sosial Budaya. Pustaka Pelajar.

Ricoeur, P. (1974). The Conflict of Interpretations: Essays in Kermeneutics (D. Ihde (ed.)). North Western University.

Sutanto, H. (2010). Perjanjian Baru Interlinear Yunani - Indonesia dan Konkordansi Perjanjian Baru (PBIK). Lembaga Alkitab Indonesia.

Turner, G. (1992). British Cultural Studies: An Introduction. Routledge.

Zare-Behtash, E., \& Firoozkoohi, S. (2009). A Diachronic Study of Domestication and Foreignzation Strategies of Culture-Specific Items: in English Persian Translation of Hemingway's Work. 
World Applied Sciences Journal, 7(12), 1576-1582.

Zoest, A. V. (1993). Semiotika: Tentang Tanda, Cara Kerjanya dan Apa yang Kita Lakukan Dengannya. Yayasan Sumber Agung. 